\title{
セミサブ型海上橋梁のための浮体式水中基礎に作用する 波力の評価
}

\author{
渡邊 英一* ・間 瀬 肇** - 宇都宮智昭 $* * *$ \\ 吳冲 $* * * *$. 高橋道生 ${ }^{* * * *}$. 飯田毅 $* * * * *$
}

\section{1.はじめに}

近年, 長距離海上横断のための海上橋梁の需要はます ます高まってきているが, 従来の橋梁形式では大水深, あるいは，軟弱地盤域において海中橋梁基礎の施工が困 難であり，この様な条件下で有利と考えられる浮体橋梁 の検討が始められている．既に比較的波浪条件の穏やか な水域においては，連続ポンツーン浮体を用いた浮体橋 梁(Lwin，1993)，あるいは，独立ポンツーン浮体を弾性 支承として用いる橋梁 (Solland ら，1993）が海外に扔い て実現している。しかしながら，このような従来形式の ポンツーン型浮体橋梁は波浪の影響を強く受けるため, 波浪条件の厳しい我が国の海域においてそのまま適用す ることは困難である（運輸省港湾局技術課ら，1991）。

そこで, 耐波浪特性に優れる, 緊張係留された水中浮 体基礎で橋脚を支持する形式のセミサブ型海上橋梁につ いて考える．浮体主要部を海中に沈めることでこれに作 用する波力を低隇し，また，緊張係留することで波浪動摇 を大幅に低減する。このような形式の海上橋梁の実現性 を検討するためには, 先ず, 浮体式水中基礎に作用する波 力や潮流力などの外力の把握が不可欠と考えられる.

以上のような背景のもと; 本研究では浮体式水中基礎 に作用する波力および潮流力に関する実験を行い，その 評価法を確立することを目的とする，二次元造波水槽に おいて $1 / 100$ スケールモデルに対する波力を測定し，ポ テンシャル理論に基づく理論值と比較を行い，その適用 性について調べる．また，波力算定プログラムを用いた 数值計算により最適なハル形状についての考察も行う.

\section{2. 実験・解析方法}

実験は，長さ $30 \mathrm{~m} \times$ 幅 $90 \mathrm{~cm} \times$ 高さ $100 \mathrm{~cm}$ の寸法を 有する二次元造波水槽で行った。造波機は油圧サーボ型 ピストン式造波形式で，任意不規則波が発生可能である が，本実験では規則波に対してのみの測定を行った。ま
た，水槽の側面に取り付けられた循環用パイプの中の水 をインバータープロペラの回転数を制御することによっ て水槽内に定常流を発生させることができる.

模型の設置状況を図一1に示す. 使用した構造物模型 はアクリル製で実物の $1 / 100$ スケールのモデルとし，直 径 $10 \mathrm{~cm}$ 長さ $30 \mathrm{~cm}$ の円筒形浮体基礎（ハル）と，直径 $2.5 \mathrm{~cm}$ 高さ $35.5 \mathrm{~cm}$ の円形断面橋脚 (カラム) を間隔 25 $\mathrm{cm}$ で 2 本有するものとし， 2 本のカラムの上部を一枚 のアクリル板で接合した。このアクリル板の中心軸上に 三分力検出器 (日章電機 LMC-3501) を設置することに よって,模型全体に働く流体力を測定できるょうにした。

測定項目は，入射波高（容量式波高計：ケネック $\mathrm{CH} 403 \mathrm{~A})$ 及び, 三分力検出器の出力による荷重值 $\left(F_{x}\right.$, $\left.F_{y}, M_{z}\right)$ とした。いずれも，A/D コンバー夕を介してデ ジタルデータとしてパソコンに取り込んだ。

理論值の算出にあたっては，橋脚部（カラム）に働く 波力についてはモリソン式で，浮体主要部（ハル）に働 く波力については，ポテンシャル理論を用いて求める. ポテンシャル理論に基づく波力の算出にあたっては, 著 者らの開発した, 微小振幅波理論に基づく三次元特異点 分布法を用いた波力算定プログラム (Watanabe ら, 1994）を利用した。

\section{3. 実験結果及び考察}

\section{1 波力と入射波高の関係}

実験結果は時刻歴データとして採集されるので, 測定

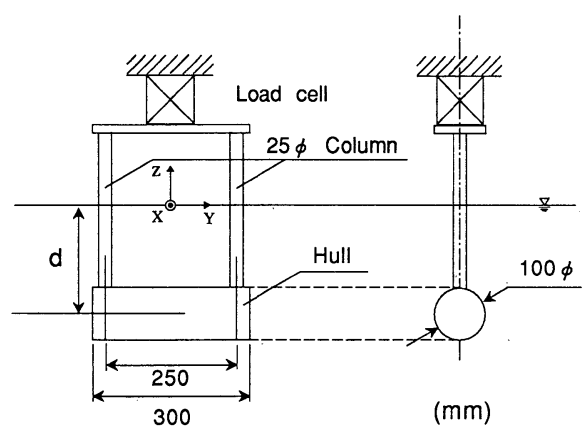

図-1 浮体式水中基礎模型 


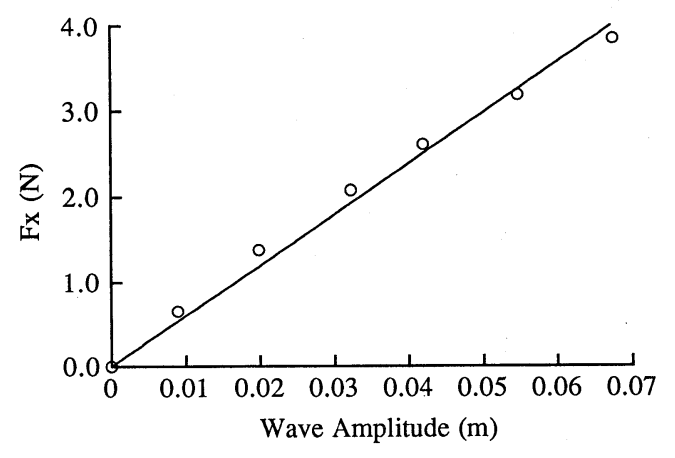

図一2 波力と入射波高の関係

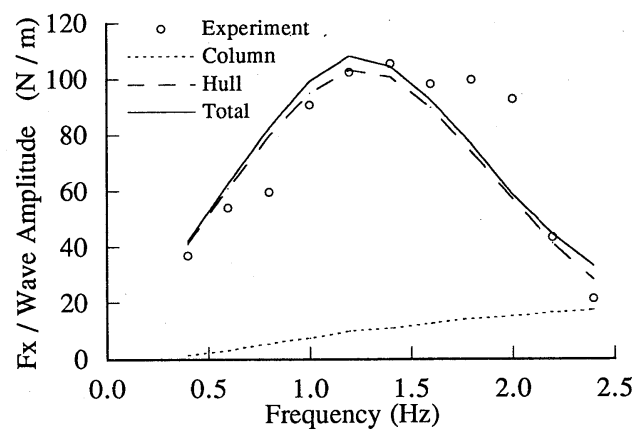

図一3 X方向波力と入射波周波数の関係

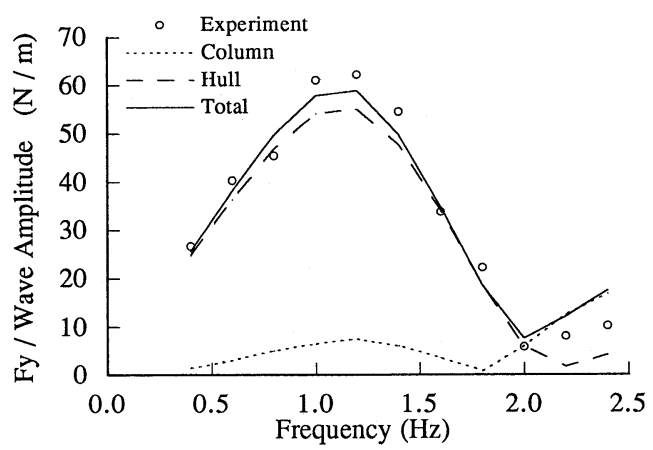

図一4 $Y$ 方向波力と入射波周波数の関係

$\mathrm{Hz}$ の時の波長は $48 \mathrm{~cm}$ であり, その半波長がハル間隔 $25 \mathrm{~cm}$ にほほ等しいため 2 本のハルに衝く力が打ち消し あうためである.また, ハル間隔が波長と等しいときは, 2 本のハルに働く力が全く打ち消されないので大きな波 力を生じる. 今回の実験では $f=2.4 \sim 2.5 \mathrm{~Hz}$ 付近の時 である.

ハルに働くカとカラムに働く力の位相を考慮した上で 全波力を求めると, ハルに働く力が支配的になる。なお， カラムに働く力は慣性力と抗力からなっており, これら の合力はハルに働く力とは $\pi / 3$ から $\pi / 2$ ほど位相がず れているため, ハルに働く力の大きさとカラムに働く力 の大きさの単純和が模型に働く波力の大きさとなるわけ ではない. 入射角が $\alpha=90^{\circ}$ の場合は高周波域でカラムに 働く力が大きくなるので, この力が支配的になる.

\section{3 八ルの設置水深による影響}

水深 $h=65 \mathrm{~cm}$, 波の入射角 $\alpha=0^{\circ}$ の場合において, 八 ルの設置水深 $d$ を $10,15,20 \mathrm{~cm}$ にしたときの実験結果 を図一5 に示す. 設置水深別に $F_{x} / \zeta_{a}$ の実験值の最大值を 調べると, $d=10 \mathrm{~cm}$ の時は $149.19 \mathrm{~N} / \mathrm{m}, d=15 \mathrm{~cm}$ の時 は $105.42 \mathrm{~N} / \mathrm{m}, d=20 \mathrm{~cm}$ の時は $92.82 \mathrm{~N} / \mathrm{m}$ であり,八 ルを沈めるほどこれに作用する波力は小さくなることが わかる，深海においては，水深が深くなるほど水粒子の $\mathrm{Hz}$ 付近で極大值をとった後, 減少し始め $f=1.8 \mathrm{~Hz}$ 付近 で極小值をとった後再び増加し始める.これは $f=1.8$ 致している. ハルに働く波力は周波数依存性を有してお り, ほほ，周波数 $f=1.0 \sim 1.4 \mathrm{~Hz}$ 付近で最大值を有して いる. カラムに働く波力は, 入射角 $\alpha=0^{\circ}$ の時は周波数と ともに増加するが，入射角 $\alpha=90^{\circ}$ の時は周波数 $f=1.2$

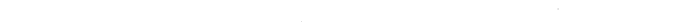




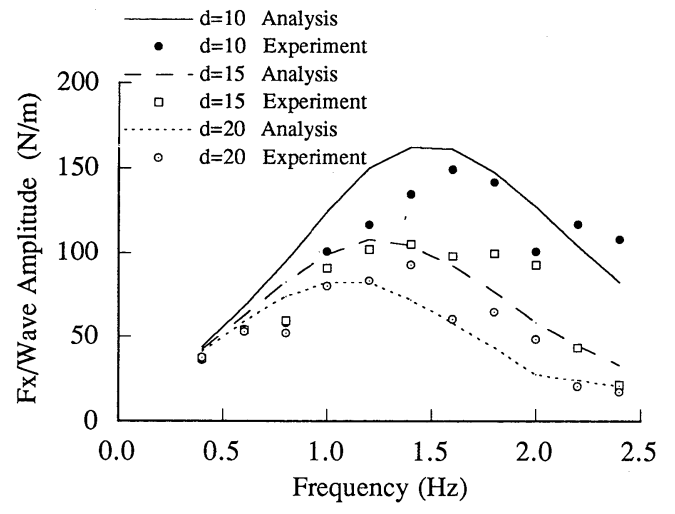

図一5ハル設置水深による波力の変化

移動加速度は小さくなるため, 八ルの受ける波力は小さ くなる。

深海における微小振幅波理論及びモリソン式を使って $F_{x} / \zeta_{a}$ について考えると次式のように表される.

$$
\frac{F_{x}}{\zeta_{a}}=C_{m} \rho g k V e^{-k d}
$$

ここに, $k$ : 波数, $V$ : 浮体式水中基礎の体積, $d$ : 静水面からハルの中心までの深さである。 上式ょり, $F_{x} / \zeta_{a}$ の值は八ルの設定水深 $d$ に関して $\exp (-k d)$ の項 により指数関数的に減少する事がわかる。このことから も，八ルに作用する波力を低減する上で，この設置水深 を深くすることが有利であることがわかる.

$F_{x} / \zeta_{a}$ が極值をとるときの周波数は次式を満たす。

$$
\frac{\partial}{\partial k}\left(\frac{F_{x}}{\zeta_{a}}\right)=0
$$

よって,

$$
f_{\text {peak }}=\frac{1}{2 \pi} \sqrt{\frac{g}{d}}
$$

$d=10 \mathrm{~cm}$ のとき $f=1.576 \mathrm{~Hz}, d=15 \mathrm{~cm}$ のとき $f=$ $1.287 \mathrm{~Hz}, d=20 \mathrm{~cm}$ のとき $f=1.114 \mathrm{~Hz}$ と計算される. 图一5においてもこれらの值付近で最大值をとってお り, ハルの深さを変えることによって $F_{x} / \zeta_{a}$ の分布が低 周波側へ移動するといえる. また, この時の $F_{x} / \zeta_{a}$ の值を (1) 式により求めると,

$$
F_{x} / \zeta_{a}=C_{m} \rho g V /(e d)
$$

となる.ここで $C_{m}=2.0$ とすると, $d=10 \mathrm{~cm}$ のとき $F_{x} / \zeta_{a}=170 \mathrm{~N} / \mathrm{m}, d=15 \mathrm{~cm}$ のを $F_{x} / \zeta_{a}=113 \mathrm{~N} / \mathrm{m}$, $d=20 \mathrm{~cm}$ のとき $F_{x} / \zeta_{a}=85.0 \mathrm{~N} / \mathrm{m}$ となり, ほぼ実験值 に一致する。従って, 式 (3), (4) は近似式として有効 に用いることができる.

\section{4 潮流力について}

造波水槽に付設されている定常流発生部を作動させて 潮流を起こし, 模型が流れ方向に受ける力を測定した。

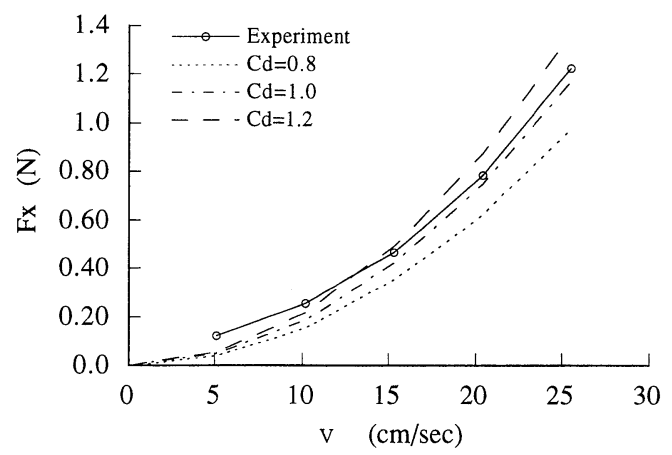

図一6 X方向潮流力と流速の関係

ハル及びカラムに作用する力は次の抗力式を使って評価 する。

$$
F_{\mathrm{drag}}=\frac{1}{2} C_{d \rho} \rho A v^{2}
$$

ここで, $A$ : 投影面積, $v$ : 流速である. 実験は水深 $h$ を $65 \mathrm{~cm}$, 八ルの設置水深 $d$ を $15 \mathrm{~cm}$ として入射角 $\alpha$ が $0^{\circ} \sim 90^{\circ}$ の場合について, 流れ方向に受ける力を測定し た. 実験值と抗力式による計算値を $\alpha=0^{\circ}$ の場合につい て図一6に示す.この場合, 抗力係数を $0.8 \sim 1.0$ とすれ ば抗力式で潮流力を評価できる.また, $\alpha=0^{\circ} \sim 90^{\circ}$ の領域 で, $C_{d}=0.8 \sim 1.2$ 程度となることがわかった。

\section{4. ハル形状の効果に関する数值解析}

浮体式水中基礎を使って海上橋梁を作る場合，基礎部 分の浮力一定（体積一定）の条件のもとでこれに働く波 カがより小さい方が望ましい.ここでは，先に述べた波 力算定プログラムによって流体力学的に有利なハル形状 を考える.

\section{1 単ハル形状の効果}

先ず水中にハルが 1 つだけある場合を考える，ハルの 形状としては同底部投影面積，同体積を有する，円筒 (Cylinder), 直方体 (Hexahedron), 両端半球付き円筒 (Cylinder with half-spheres) の 3 種類を考えた. ハルの 形状図を図一7に示す.八ルの設置環境は水深 $h=65$ $\mathrm{cm}$, 八ルの設置水深 $d=15 \mathrm{~cm}$ とし, 波の入射波 $\alpha$ が $0^{\circ}$ の場合について計算を行った。 $\alpha=0^{\circ}$ のきの $F_{x} / \zeta_{a}$, $F_{z} / \zeta_{a}$ と周波数の関係を図一8,9 亿示す.

入射波が $0^{\circ}$ のきの $F_{x} / \zeta_{a}$ について考える. 形状別の 波力の大きさを考えると周波数によらず，円筒と両端半 球付き円筒はほぼ等しい, あるいは両端半球付き円筒が 円筒をやや下回っている. 直方体については, 周波数 $f=$ $1.6 \mathrm{~Hz}$ 以下の領域において 2 者より多少大きな值をと る. 周波数 $f=1.2 \mathrm{~Hz}$ 付近の波力が最大となる領域で, この違いが大きい. ただし， $F_{x} / \zeta_{a}$ は $1.8 \mathrm{~Hz}$ 以上の領域 で 2 者より小さな值をとる. 

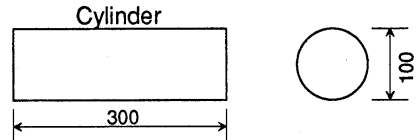

Hexahedron
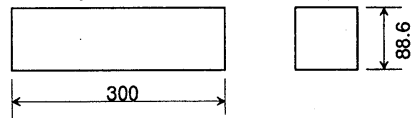

Cylinder with half-spheres

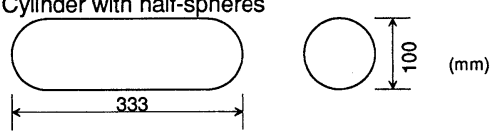

図一7 ハル形状図

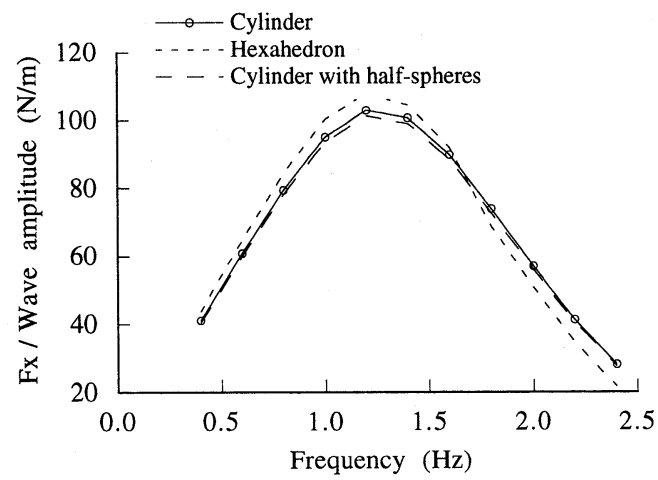

図一8 X方向波力のハル形状による変化

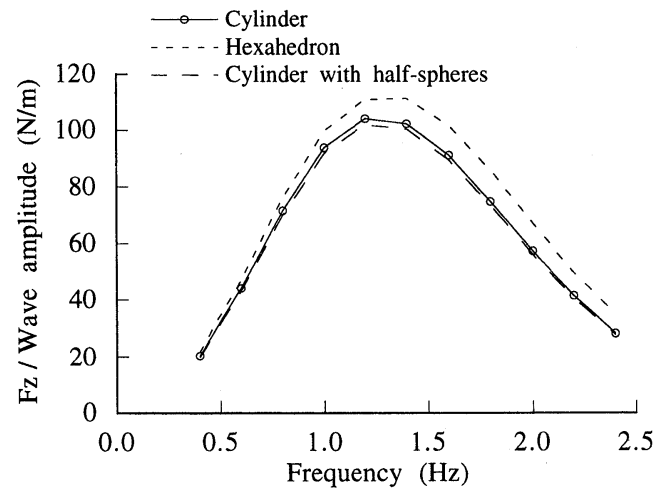

図一9 Z 方向波力のハル形状による変化
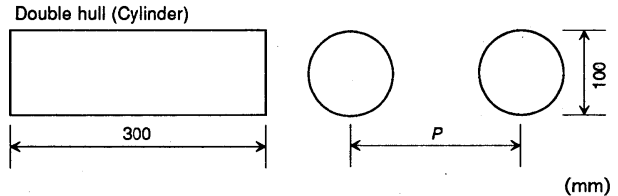

図一10 ダブル・ハル構造の形状図
次に $F_{z} / \zeta_{a}$ について考える. 円筒と両端半球付き円筒 の值はほぼ等しいが, 周波数 $f=1.0 \mathrm{~Hz}$ 以上の領域にお いて, 直方体は 2 者よりも多少大きな値を示しており, 鉛直方向に大きな力をうけることがわかる. 以上のよう に波力の影響を考えると，八ル形状として直方体は不利 であり，ここで検討した中では半球付き円筒形が最も有 利となる。

\section{2 ダブル・ハル構造の効果}

浮体式水中基礎を現実の設計に用いる場合, 静水力学 的安定を増すために，基礎として $2 つ$ つルを持った構 造を考えることがあると思われる.そこで, このダブル・ ハル構造の効果についての検討を行った. ハルとして長 さ $30 \mathrm{~cm}$, 直径 $10 \mathrm{~cm}$ の円筒を間隔 $P=20,25,30 \mathrm{~cm}$ で 配置した場合を比較する (図一10)。設置環境は水深 $h=$ $65 \mathrm{~cm}$, 設置水深 $d=15 \mathrm{~cm}$ とした。

入射角 $\alpha=0^{\circ}$ のときの $F_{x} / \zeta_{a}$ と周波数の関係を図-11 に, $\alpha=90^{\circ}$ のときの $F_{y} / \zeta_{a}$ と周波数の関係を図-12 に示 す.

ダブル・ハル構造に入射角 $\alpha=0^{\circ}$ で入射する波による 合波力は，位相差を考慮することによって次式で近似的

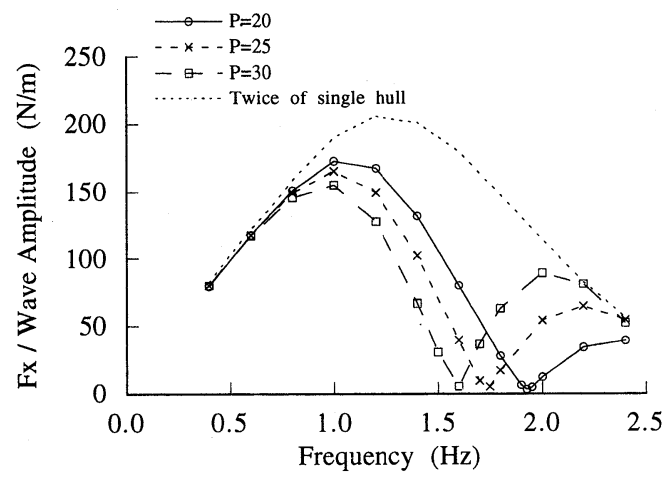

図一11 X方向波力のハル間隔による変化

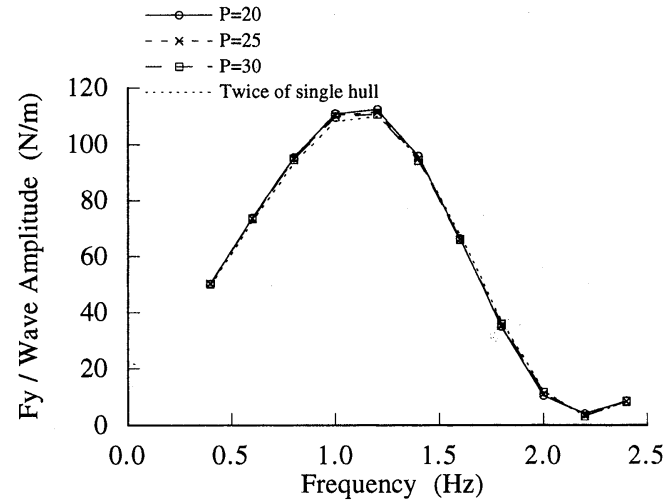

図一12 $Y$ 方向波力のハル間隔による変化 
に表せる.

$$
F_{\text {total }}=2 F_{0} \cos \left(\frac{\pi P}{L}\right) \text {. }
$$

ここで, $F_{0}$ ：単一ハルに作用する波力, $P$ : ハル間隔,

$L ：$ 波長である.

すなわち, ダブル・ハル構造では入射角 $\alpha=0^{\circ}$ で, ハル

間隔 $P$ が半波長 $L / 2$ に等しいとき, 構造物に働く波力は 打ち消し合う.この時の周波数 $f_{c}$ を求めると

$$
f_{c}=\sqrt{\frac{g}{2 \pi L}}=\sqrt{\frac{g}{4 \pi P}}
$$

となる.これを計算すると, $P=20 \mathrm{~cm}$ のとき $f=1.98$ $\mathrm{Hz}, P=25 \mathrm{~cm}$ のとき $f=1.77 \mathrm{~Hz}, P=30 \mathrm{~cm}$ のとき $f=$ $1.61 \mathrm{~Hz}$ となり, いずれも数值解析值と一致している. 逆に，ハル間隔が波長と等しいときは，2つのハルに 同位相で波が入射するため単一ハル 2 本分の波力が働 き, 低減効果は見られない. 単一八ル 2 本分の波力と夕゙ ブル・ハル構造に働く合波力を比較すると, ダブル・ハ ル構造を採用することによって構造物に働く波力を低減 でき，有効と思われる．また， $\alpha=90^{\circ}$ のきはダブル・ハ ル構造と単一八ル 2 本分の波力ではほとんど差がない.

\section{5. 結}

\section{言}

本報告の主要な結論㾕まとめると,以下のようになる.
（1）波力算定プログラムによる理論值は，実験值と ほほ一致した.よって, ハルに働く波力はポテンシャル 理論で, カラムに働く波力はモリソン式で求めればよい ことがわかった．また，ハルに働く波力をモリソン式に よる近似式（(1)～(4)) で近似的に評価することがで きる。

（2）水中浮体基礎に働く潮流力は, 抗力式で評価で き, $C_{d}=0.8 \sim 1.2$ を用いればよい.

（3）波力算定プログラムによる計算結果より，ハル 形状としては, 今回比較した三者の中では, 両端半球付 き円筒が有利となる.またダブル・ハル構造にすること により，基礎に働く合波力を低減させることができる.

\section{参考 文 献}

運輸省港湾局技術課・財) 沿岸開発技術研究センター(1991)： フ ローテイングブリッジ開発基礎調査報告書, $72 \mathrm{p}$.

Lwin, M. M. (1993): The Lacy V. Murrow floating bridge, USA, Structural Engineering International, March, pp. 145-148.

Solland, G., S. Haugland and J.H. Gusyaven (1993): The Bergsoysund floating bridge, Norway, Structural Engineering International, March, pp. 142-144.

Watanabe, E., C. Wu and T. Utsunomiya (1994): Wave forces on large offshore structures: an effective calculation of Green's function, Proc. of the Fourth ISOPE, pp. 252-255. 